\title{
Quality characteristics of bisir 'Barhee' dates during cold storage as affected by postharvest dipping in gibberellic acid, naphthaleneacetic acid and benzyladenine
}

\author{
Adel D. AL-QurashI ${ }^{1 *}$, Mohamed A. AWAD ${ }^{1,2}$
}

${ }^{1}$ Fac. Meteorol. Environ. Arid land Agric., Dep. Arid land Agric., King Abdul-Aziz Univ., PO Box. 80208, Jeddah,

Saudi Arabia

aalqurashi@kau.edu.sa

${ }^{2}$ Fac. Agric., Pomol. Dep., Mansoura Univ., El-Mansoura, Egypt

mawad@mans.edu.eg

${ }^{*}$ Correspondence and reprints

Received 2 November 2010 Accepted 20 January 2011

Fruits, 2011, vol. 66, p. 343-352 (C) 2011 Cirad/EDP Sciences All rights reserved DOI: $10.1051 /$ fruits/2011048 www.fruits-journal.org

RESUMEN ESPAÑoL, p. 352
Quality characteristics of bisir 'Barhee' dates during cold storage as affected by postharvest dipping in gibberellic acid, naphthaleneacetic acid and benzyladenine. Abstract - Introduction. There is a growing demand in the international market for excellent-quality dates of cultivars such as 'Barhee' that are consumed at the bisir stage. Materials and methods. The effects of $\mathrm{GA}_{3}$, BA and NAA postharvest dipping treatments at different concentrations on the quality characteristics of bisir 'Barhee' dates during cold storage were investigated. Results and discussion. The total soluble solids (TSS) concentration was lower in the BA- and NAA-treated fruit than in control fruit. Similarly, the $\mathrm{GA}_{3}$-treated fruit at $150 \mathrm{mg} \cdot \mathrm{L}^{-1}$ contained a lower TSS concentration than control fruit. The $\mathrm{GA}_{3}$ at $150 \mathrm{mg} \cdot \mathrm{L}^{-1}, \mathrm{BA}$ at $60 \mathrm{mg} \cdot \mathrm{L}^{-\mathrm{P}}$ and NAA at $(100$ and 150$) \mathrm{mg} \cdot \mathrm{L}^{-1}$ increased vitamin C concentration compared with other treatments. Acidity and total phenol concentrations were not affected by any of the treatments. The date soluble tannin concentration was higher than control fruit only in the dates treated with $20 \mathrm{mg} \mathrm{BA} \cdot \mathrm{L}^{-1}$. The weight loss $\%$ was lower in the BA-treated fruit at $(20$ and 60) $\mathrm{mg} \cdot \mathrm{L}^{-1}$ compared with all other treatments, while $\mathrm{GA}_{3}$ treatment at $50 \mathrm{mg} \cdot \mathrm{L}^{-1}$ increased fruit weight loss \% compared with control fruit. The percentage of dates at the rutab stage (index for fruit ripening) was lower for fruit treated with $\mathrm{GA}_{3}$ than for control fruit. Also, the rutab stage $\%$ was lower for fruit treated with BA at $40 \mathrm{mg} \cdot \mathrm{L}^{-1}$ and NAA at $150 \mathrm{mg} \cdot \mathrm{L}^{-1}$ compared with control fruit. The TSS concentration decreased during storage from the initial day to day 20. However, there were no further decreases in the TSS concentration after ( 40 and 60 ) days of storage. The acidity concentration was slightly increased during storage. The vitamin $\mathrm{C}$ concentration increased until 40 days of storage, then a slight decrease occurred. The total phenol concentration decreased after ( 40 and 60) days of storage compared with the initial level. The soluble tannin concentration slightly increased at day 20 but sharply decreased after (40 and 60) days of storage compared with the initial level. Both weight loss and rutab stage \% gradually increased during storage. There were significant interaction effects between growth regulators and storage period on TSS, vitamin C concentration, weight loss and rutab stage \%

Saudi Arabia / Phoenix dactylifera / fruits / developmental stages / cold storage / quality / chemicophysical properties / ripening / maturity

Qualité des dates 'Barhee' au stade bisir stockées au froid après trempage post récolte dans l'acide gibbérellique, l'acide naphtalène et la benzyladénine.

Résumé - Introduction. Il existe une demande croissante dans le marché international pour des dates d'excellente qualité telles que le sont celles du cultivar 'Barhee' qui sont consommées au stade bisir. Matériel et méthodes. Les effets du traitement de dates 'Barhee' au stade bisir par trempage après récolte dans des solutions de $\mathrm{GA}_{3}$, BA et ANA à différentes concentrations ont été étudiés sur certaines caractéristiques de qualité des fruits pendant leur stockage au froid. Résultats et discussion. La concentration en solubles solides totaux (SST) dans les fruits traités avec BA et NAA a été plus faible que dans les fruits témoins. De même, les fruits traités avec $150 \mathrm{mg} \mathrm{GA} \cdot \mathrm{L}^{-1}$ ont montré une concentration de SST plus faible que les fruits témoins. Les traitements avec $150 \mathrm{mg} \mathrm{GA} \cdot \mathrm{L}^{-1}$, $60 \mathrm{mg} \mathrm{BA} \cdot \mathrm{L}^{-1}$ et $(100 \mathrm{et} 150) \mathrm{mg} \mathrm{NAA} \cdot \mathrm{L}^{-1}$ ont augmenté la concentration en vitamine $\mathrm{C}$ des dates par rapport aux autres traitements. L'acidité et la concentration en phénols totaux n'ont été affectés par aucun des traitements. La concentration en tanins solubles des dates traitées ne s'est révélée plus élevée que celle des fruits témoins que dans les fruits traités avec $20 \mathrm{mg} \mathrm{BA} \cdot \mathrm{L}^{-1}$. La perte de poids des fruits traités avec $(20$ et 60$) \mathrm{mg} \mathrm{BA} \cdot \mathrm{L}^{-1}$ a été inférieure à celle des fruits de tous les autres traitements, tandis que le traitement à $50 \mathrm{mg} \mathrm{GA} \cdot \mathrm{L}^{-1}$ a augmenté la perte de poids des dates par rapport aux fruits témoins. Le pourcentage de dates au stade rutab (indice de maturation des fruits) a été plus faible pour les fruits traités avec $\mathrm{GA}_{3}$ que pour les fruits témoins. En outre, ce pourcentage a été plus faible pour les fruits traités avec $40 \mathrm{mg} \mathrm{BA} \cdot \mathrm{L}^{-1}$ et $150 \mathrm{mg} \mathrm{NAA} \cdot \mathrm{L}^{-1}$ que pour les fruits témoins. La concentration en SST a diminué du premier au vingtième jour de stockage. Cependant, il n'y a pas eu de nouvelles baisses de cette concentration après ( 40 et 60) jours de stockage. L'acidité a été légèrement augmentée durant le stockage. La concentration en vitamine $\mathrm{C}$ a augmenté jusqu'à 40 jours de stockage, puis une légère baisse s'est produite. La concentration totale en phénols a diminué après ( 40 et 60) jours de stockage par rapport au niveau de départ. La concentration des tanins solubles a légèrement augmenté jusqu'au vingtième jour, mais elle a fortement diminué après (40 et 60) jours de stockage par rapport au niveau de départ. La perte de poids des dates et le taux de fruits au stade rutab ont été progressivement augmentés pendant le stockage. Il y a eu des interactions significatives entre les régulateurs de croissance et la période de stockage sur la concentration en SST et en vitamine $\mathrm{C}$, ainsi que sur le taux de perte de poids et sur celui de fruits au stade rutab.

Arabie Saoudite / Phoenix dactylifera / fruits / stade de développement / stockage au froid / qualité / propriété physicochimique / mûrissage / maturité 


\section{Introduction}

The consumption of fruit and vegetables is widely regarded as important and good for health. Indeed, date palm fruit possesses antioxidant and antimutagenic properties in vitro [1] and this is due, partly, to its high content of polyphenolic compounds, important dietary constituents [2]. Date palm is the most successful and an extremely important subsistence crop in most of the arid hot regions [3, 4].

All edible cultivars of date pass through five distinct stages of development and ripening. These stages are designated by Arabic terms and used universally: hababouk, kimri, bisir or khalal, rutab and tamer are used to represent, respectively, the cell division, cell elongation or the immature green, the mature firm full-colored, the soft brown and the hard raisin-like stages of development. Generally, whole dates are harvested and marketed at three stages of their development; mainly bisir or khalal, rutab and tamer, depending on cultivar characteristics, especially soluble tannin level, climatological conditions and market demand [4-6].

There is a growing demand in the international market for excellent-quality dates of cultivars such as 'Barhee', 'Medjool', 'Deglet Nour', 'Hayany' and 'Zaghloul' [3, 6]. 'Barhee' is a mid-season cultivar extensively cultivated in the Gulf region. 'Barhee' dates are different than other cultivars in which fruit are marketed and consumed fresh at the mature full yellow (bisir) stage as a crispy apple-like fruit due to low contents of soluble tannins [3]. At the rutab stage (ripening), fruit become softer and sweeter but their market value decreases.

Under the conditions of the Kingdom of Saudi Arabia (KSA), 'Barhee' dates reach the bisir stage during the extremely hot dry summer (early to mid-July). After harvest, fruit ripen rapidly, especially in ambient conditions, and thus lose much of their marketing value. The ability to control fruit ripening following harvest and thus prolong shelf life is a critical requirement in order to market the harvested bisir fruit with minimal physiological and physical disorders. Generally, there is little literature information on storage of 'Barhee' dates or on other cultivars that are especially consumed at the bisir stage. It is well known that hormones have an important role in fruit maturation and ripening [7]. Ethylene is effectively connected with fruit maturity, ripening and postharvest softening of especially climacteric fruits [8, 9]. At early ripening stages of the 'Negros' date palm cultivar growing in Spain, a small peak in ethylene production was detected followed by a peak in the respiration rate, suggesting that date could be considered as a climacteric fruit, with ethylene being responsible for the ripening processes [10]. Preharvest ethrel application increased ripening of 'Helali' dates, while ABG-3168 (an ethylene blocker) at $3.33 \mathrm{~g} \cdot \mathrm{L}^{-1}$ inhibited ripening, suggesting a role for ethylene in the ripening process [4]. Cold storage inhibited fruit ripening and prolonged shelf life of bisir 'Zaghloul' dates compared with ambient conditions [11, 12]. Low fruit calcium levels have generally been associated with reduced postharvest life and increased physiological disorders of apples and pears [13]. Calcium has also been utilized in preharvest and postharvest treatments for prolonging the bisir stage of 'Zaghloul' dates during storage in either ambient or refrigeration conditions $[11,12]$. However, pre- and postharvest treatments with $0.5-6 \%(\mathrm{w} / \mathrm{v})$ calcium chloride solution failed to extend shelf life of bisir 'Barhee' dates during storage in ambient conditions and cold storage [6]. The application of $\mathrm{GA}_{3}$ on dates at the kimri stage increased fruit size and yield per tree but delayed fruit ripening and induced a high variation in ripening within the one bunch [14, 15]. Preharvest application of $\mathrm{NAA}$ at (40 and 60$) \mathrm{mg} \cdot \mathrm{L}^{-1}$ on 'Zahdi' dates 15-16 weeks after pollination (late kimri stage) increased fruit size and delayed ripening by one month [16]. The application of NAA at (50 and 100) $\mathrm{mg} \cdot \mathrm{L}^{-1}$ on 'Sewy' dates at 10-30 days following the fruit set stage increased fruit drop and decreased yield but improved fruit weight and quality compared with control [17]. The application of NAA or a mixture of growth regulators (NAA, $\mathrm{GA}_{3}$ and ethephone) on 'Khenazi' dates at 20 days following pollination delayed fruit ripening for one month, decreased dry matter, and increased fruit weight and yield per tree [18]. Also, the application of benzyladenine (BA) and other cytokinines effectively 
delayed ripening of apples and other fruits [19].

We assumed that the postharvest dipping of bisir 'Barhee' dates in growth regulators might eliminate the negative aspects of the preharvest application concerning the uniformity of fruit ripening. Therefore, the objective of our study was to evaluate the effect of postharvest dipping of bisir 'Barhee' dates in $\mathrm{GA}_{3}$, BA and NAA on fruit quality characteristics during cold storage as an attempt to inhibit ripening and prolong shelf life.

\section{Materials and methods}

\subsection{Plant materials and experimental procedure}

In the 2010 growing season, sound bisir 'Barhee' dates were harvested (July 7) from uniform trees originated from offshoots and growing at the research farm of the College of Meteorology, Environment and Arid Land Agriculture in Hada Al-Sham region, KSA. Fruit samples were subjected to one of the growth regulator dipping treatments as follows: $\mathrm{GA}_{3}$ at $(50,100$ and 150$) \mathrm{mg} \cdot \mathrm{L}^{-1} ; \mathrm{BA}$ at $(20,40$ and 60$) \mathrm{mg} \cdot \mathrm{L}^{-1}$; and NAA at $(50$, 100 and 150$) \mathrm{mg} \cdot \mathrm{L}^{-1}$. A control treatment was included in which the fruits were dipped in water. Each treatment was replicated three times (300 fruits per replicate) as a factorial experiment in a complete randomized block design. A non-ionic wetting agent (Tween 20 surfactant) at $0.01 \%$ was added to all treatments.

The treated fruits were kept in perforated (10 perforations) plastic boxes in a refrigerator $\left[(1 \pm 1)^{\circ} \mathrm{C}\right.$ and $\left.90-95 \mathrm{RH}\right]$. During storage the number of ripe (rutab) fruit was periodically recorded and expressed as a percentage. Fruit that showed softening for about $10 \%$ (visually estimated) of its total area was considered rutab/ripe. The percent of weight loss was calculated on an initial weight basis.

At harvest, additional fruit samples (20 fruit each) were collected for initial quality measurements. Samples of bisir fruit (10 fruit each) were periodically withdrawn during storage for quality measurements [total soluble solids (TSS) contents, acidity, vitamin $\mathrm{C}$, total phenols and soluble tannins].

\subsection{TSS, acidity and vitamin C determinations}

A homogeneous sample was prepared from these 10 fruits per replicate for measuring TSS, acidity, vitamin C, total phenols and soluble tannins. Five grams of fruit tissue (including skin and flesh) was homogenized with $10 \mathrm{~mL}$ of distilled water (for measuring TSS and acidity) or with $10 \mathrm{~mL}$ of oxalic acid (for measuring vitamin C) in a blender and then centrifuged. The supernatant was collected and used as fruit juice, considering the dilution factor. TSS were measured as Brix \% in fruit juice with a digital refractometer (DR 6000, A. Kruss Optronic GmbH, Hamburg, Germany). Titratable acidity was determined in fruit juice by titrating with $0.1 \mathrm{~N}$ sodium hydroxide in the presence of phenolphthalein as an indicator, and the results were expressed as a percentage of malic acid [4]. Ascorbic acid (vitamin C) was measured by the oxidation of ascorbic acid with 2,6-dichlorophenol endophenol dye and the results were expressed as $\mathrm{mg} \cdot 100 \mathrm{~g}^{-1}$ tissues [4].

\subsection{Total phenol determination}

Total phenols were measured according to Velioglu et al. [20] using Folin-Ciocalteu reagent. Two hundred milligrams of fruit tissue (including skin and flesh) were extracted with $2 \mathrm{~mL}$ of $50 \%$ methanol for $2 \mathrm{~h}$ with shaking at ambient temperature. The mixture was centrifuged for $10 \mathrm{~min}$, and the supernatant was decanted into 4-mL vials. Then, $200 \mu \mathrm{L}$ of the extract was well mixed with $1.5 \mathrm{~mL}$ Folin-Ciocalteu reagent (previously diluted ten-fold with distilled water) and allowed to stand for $5 \mathrm{~min}$ at ambient temperature. $1.5 \mathrm{~mL}$ of $20 \%$ sodium carbonate was added. After 90 min, absorbance was measured at $750 \mathrm{~nm}$ using a UV-Vis spectrophotometer. The blank contained only water and the reagents. Total phenols were quantified from a calibration curve obtained by measuring the absorbance of known concentrations of gallic acid. 


\subsection{Soluble tannin determination}

Soluble tannins were measured according to Taira [21]. Five grams of fruit tissue (including skin and flesh) were homogenized with $25 \mathrm{~mL}$ of $80 \%$ methanol in a blender and then centrifuged. The supernatant was collected and the precipitant was re-extracted with 80\% methanol and centrifuged. The combined supernatant was brought to $100 \mathrm{~mL}$ with distilled water. Then the 1-mL sample solution was mixed with $6 \mathrm{~mL}$ distilled water and $0.5 \mathrm{~mL}$ Folin-Ciocalteu reagent (previously diluted ten-fold with distilled water). After exactly $3 \mathrm{~min}$, one $\mathrm{mL}$ of saturated sodium carbonate was added. Then $1.5 \mathrm{~mL}$ distilled water was added and mixed well (total, $10 \mathrm{~mL}$ ) and then left for $1 \mathrm{~h}$ at ambient temperature before measuring absorbance at $750 \mathrm{~nm}$ using a UV-Vis spectrophotometer. The blank contained only water and the reagents. Soluble tannins were quantified from a calibration curve obtained by measuring the absorbance of known concentrations of gallic acid.

\subsection{Statistical analysis of data}

The obtained data were statistically analyzed as a factorial experiment in a complete randomized block design with three replicates by analysis of variance (ANOVA) using the statistical software package SAS (SAS Institute Inc., 2000, Statistical Software, Cary, NC., USA). Comparisons between means were made by the F-test and the least significant differences (LSD) at $\mathrm{P}=5 \%$.

\section{Results}

Observing the main effects of $\mathrm{GA}_{3}$, BA and NAA dipping treatments and the storage period on the quality characteristics of bisir 'Barhee' dates during cold storage, we can note that the TSS concentration was significantly lower in the BA- and NAA-treated fruit at the different levels than in control fruit (table I). However, the $\mathrm{GA}_{3}$-treated fruit only at $150 \mathrm{mg} \cdot \mathrm{L}^{-1}$ contained a significantly lower TSS concentration than control. The lowest TSS concentration was detected in the BA-treated fruit at (40 and 60) $\mathrm{mg} \cdot \mathrm{L}^{-1}$.

The concentration of titratable acidity was not significantly affected by any of the growth regulators used. The $\mathrm{GA}_{3}$ at $150 \mathrm{mg} \cdot \mathrm{L}^{-1}, \mathrm{BA}$ at $60 \mathrm{mg} \cdot \mathrm{L}^{-1}$ and NAA at (100 and 150$) \mathrm{mg} \cdot \mathrm{L}^{-1}$ significantly increased vitamin C concentration (3.11 $\mathrm{mg} \cdot 100 \mathrm{~g}^{-1}$ ) compared with all other treatments including the control. The total phenol concentration was not significantly affected by any of the growth regulators used. However, the soluble tannin concentration was significantly higher in the BA-treated fruit only at $20 \mathrm{mg} \cdot \mathrm{L}^{-1}$ than in control fruit. The loss in weight percentage was significantly lower in the BA-treated fruit at $60 \mathrm{mg} \cdot \mathrm{L}^{-1} \mathrm{com}-$ pared with all other treatments, except for the BA treatment at $20 \mathrm{mg} \cdot \mathrm{L}^{-1}$. However, the $\mathrm{GA}_{3}$ and NAA treatments at all concentrations had no significant effect on the weight loss percentage, except for the $\mathrm{GA}_{3}$ treatment at $50 \mathrm{mg} \cdot \mathrm{L}^{-1}$, that significantly increased the weight loss percentage compared with control. The rutab percentage, as an index for fruit ripening, was significantly decreased by the $\mathrm{GA}_{3}$ at all concentrations compared with control. Also, the BA at $40 \mathrm{mg} \cdot \mathrm{L}^{-1}$ and the NAA at $150 \mathrm{mg} \cdot \mathrm{L}^{-1}$ significantly decreased the rutab percentage compared with control (table I)

Regarding the effects of the storage period, the TSS concentration significantly decreased during storage from the initial day to day 20. However, there were no significant further decreases in the TSS concentration after (40 and 60) days of storage. The acidity concentration slightly but significantly increased during storage. The vitamin C concentration significantly increased during storage of (20 and 40) days, but slightly decreased after a period of 60 days of storage. The total phenol concentration significantly decreased after (40 and 60) days of storage compared with the initial level. The soluble tannin concentration slightly increased at day 20 and then sharply decreased after (40 and 60) days of storage compared with the initial level. Both the total weight loss and the rutab percentage gradually and significantly increased during the storage period (table I). 
Table I.

Quality characteristics of bisir 'Barhee' dates during cold storage at $1^{\circ} \mathrm{C}$ as affected by postharvest dipping in some growth regulators (Kingdom of Saudi Arabia, 2010 season).

\begin{tabular}{|c|c|c|c|c|c|c|c|c|}
\hline Treatments & $\begin{array}{l}\text { Dose } \\
\left(\mathrm{mg} \cdot \mathrm{L}^{-1}\right)\end{array}$ & $\begin{array}{l}\text { Total Soluble Solids } \\
\text { (Brix \%) }\end{array}$ & $\begin{array}{l}\text { Acidity } \\
(\%)\end{array}$ & $\begin{array}{l}\text { Vitamin C } \\
\left(\mathrm{mg} \cdot 100 \mathrm{~g}^{-1} \mathrm{fw}\right)\end{array}$ & $\begin{array}{l}\text { Phenols } \\
\left(\mathrm{mg} \cdot \mathrm{g}^{-1} \mathrm{fw}\right)\end{array}$ & $\begin{array}{l}\text { Tannins } \\
\left(\mathrm{mg} \cdot \mathrm{g}^{-1} \mathrm{fw}\right)\end{array}$ & $\begin{array}{l}\text { Weight loss } \\
(\%)\end{array}$ & $\begin{array}{l}\text { Rutab stage } \\
\qquad(\%)\end{array}$ \\
\hline \multicolumn{9}{|l|}{ Growth regulator } \\
\hline Control & 0 & $24.4 \mathrm{a}$ & 0.26 & $2.89 \mathrm{~b}$ & 0.44 & 5.10 bcde & $2.66 \mathrm{bcd}$ & $45.42 \mathrm{a}$ \\
\hline \multirow[t]{3}{*}{$\mathrm{GA}_{3}$} & 50 & $24.4 \mathrm{a}$ & 0.24 & $2.33 \mathrm{c}$ & 0.39 & $5.42 a b$ & $3.12 \mathrm{a}$ & $36.10 \mathrm{c}$ \\
\hline & 100 & $23.0 \mathrm{ab}$ & 0.28 & $2.77 \mathrm{~b}$ & 0.42 & 4.98 cdef & $2.83 \mathrm{bc}$ & $41.75 \mathrm{~b}$ \\
\hline & 150 & $21.2 \mathrm{~cd}$ & 0.26 & $2.94 \mathrm{a}$ & 0.39 & 4.94 def & $2.65 \mathrm{bcd}$ & $37.83 \mathrm{c}$ \\
\hline \multirow[t]{3}{*}{$\mathrm{BA}$} & 20 & $21.6 \mathrm{bcd}$ & 0.26 & $2.66 \mathrm{c}$ & 0.41 & $5.64 \mathrm{a}$ & $2.48 \mathrm{de}$ & $44.42 \mathrm{a}$ \\
\hline & 40 & $20.2 d$ & 0.26 & $2.77 \mathrm{~b}$ & 0.36 & 4.78 ef & $2.59 \mathrm{bcd}$ & $37.83 \mathrm{c}$ \\
\hline & 60 & $22.1 \mathrm{bc}$ & 0.27 & $3.11 \mathrm{a}$ & 0.46 & $4.66 \mathrm{f}$ & $2.18 \mathrm{e}$ & $46.10 \mathrm{a}$ \\
\hline \multirow[t]{3}{*}{ NAA } & 50 & 22.1 bc & 0.27 & $2.66 \mathrm{c}$ & 0.44 & $5.22 \mathrm{bcd}$ & $2.90 \mathrm{ab}$ & $44.67 \mathrm{a}$ \\
\hline & 100 & $21.9 \mathrm{bcd}$ & 0.27 & $3.11 \mathrm{a}$ & 0.51 & $5.37 \mathrm{abc}$ & $2.61 \mathrm{bcd}$ & $43.25 \mathrm{ab}$ \\
\hline & 150 & $20.8 \mathrm{~cd}$ & 0.25 & $3.11 \mathrm{a}$ & 0.45 & $5.40 a b$ & $2.55 \mathrm{~cd}$ & $41.75 \mathrm{~b}$ \\
\hline F-test & - & $\star *$ & NS & * & NS & $\star *$ & ** & $\star \star$ \\
\hline LSD 0.05 & - & 1.68 & $(-)$ & 0.44 & $(-)$ & 0.41 & 0.33 & 4.05 \\
\hline \multicolumn{9}{|l|}{ Storage period (days) } \\
\hline 0 & - & $24.7 \mathrm{a}$ & $0.21 \mathrm{~b}$ & $2.22 \mathrm{~b}$ & $0.63 \mathrm{a}$ & $5.54 \mathrm{~b}$ & $0.00 \mathrm{~d}$ & $0.00 \mathrm{~d}$ \\
\hline 20 & - & $20.8 \mathrm{~b}$ & $0.28 \mathrm{a}$ & $3.02 \mathrm{a}$ & $0.63 a$ & $6.46 \mathrm{a}$ & $1.75 c$ & $19.90 \mathrm{c}$ \\
\hline 40 & - & $21.8 \mathrm{~b}$ & $0.27 \mathrm{a}$ & $3.28 \mathrm{a}$ & $0.29 \mathrm{~b}$ & $2.60 \mathrm{c}$ & $3.41 \mathrm{~b}$ & $60.87 \mathrm{~b}$ \\
\hline 60 & - & $21.3 b$ & $0.28 \mathrm{a}$ & $2.88 a b$ & $0.16 \mathrm{~b}$ & $2.75 c$ & $5.49 \mathrm{a}$ & $86.87 \mathrm{a}$ \\
\hline F-test & - & $\star \star$ & 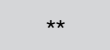 & $\star \star$ & ** & $\star \star$ & $\star \star \star ~$ & $\star \star$ \\
\hline LSD 0.05 & - & 1.17 & 0.03 & 0.28 & 0.06 & 0.26 & 0.21 & 2.56 \\
\hline $\begin{array}{l}\text { [Growth regulator } \times \\
\text { storage period] }\end{array}$ & - & ** & NS & ** & NS & NS & ** & ** \\
\hline \multicolumn{9}{|l|}{ fw: Fresh weight. } \\
\hline \multirow{2}{*}{\multicolumn{9}{|c|}{$\begin{array}{l}\text { Means within each column followed by the same letter are not significantly different at the level } P \leq 0.05 \text {. } \\
{ }^{*},{ }^{* *} \text {, significant at } P \leq 0.05 \text { and } P \leq 0.01 \text {, respectively. }\end{array}$}} \\
\hline & & & & & & & & \\
\hline \multicolumn{9}{|c|}{ (NS), Not significant; (-), not calculated. } \\
\hline
\end{tabular}

Some significant interaction effects on quality characteristics of bisir 'Barhee' dates were found between the growth regulators used and the storage period (table II-V).

The TSS concentration was significantly lower in the BA-treated fruit at $40 \mathrm{mg} \cdot \mathrm{L}^{-1}$ during the different storage periods than in control fruit. However, the $\mathrm{GA}_{3}$-treated fruit at $150 \mathrm{mg} \cdot \mathrm{L}^{-1}$ showed a lower TSS concentration at (20 and 40) days of storage than fruit of control. At 40 days of storage, the NAA-treated fruit at all concentrations contained a significantly lower TSS concentration than control fruit. The TSS concentration slightly, but significantly, fluctuated during the storage period in most treatments (table II).

The concentration of vitamin $\mathrm{C}$ in the $\mathrm{GA}_{3}$-treated fruit at $50 \mathrm{mg} \cdot \mathrm{L}^{-1}$ was lower after 40 days of storage than in control fruit. 


\section{Table II.}

The interaction effect of growth regulators and storage period on total soluble solids concentration (Brix \%) of bisir 'Barhee' dates during cold storage at $1{ }^{\circ} \mathrm{C}$ (Kingdom of Saudi Arabia, 2010 season).

\begin{tabular}{|c|c|c|c|c|c|}
\hline \multirow[t]{2}{*}{ Growth regulator } & \multirow[t]{2}{*}{$\begin{array}{c}\text { Dose } \\
\left(\mathrm{mg} \cdot \mathrm{L}^{-1}\right)\end{array}$} & \multicolumn{4}{|c|}{$\begin{array}{l}\text { Storage period } \\
\text { (days) }\end{array}$} \\
\hline & & 0 & 20 & 40 & 60 \\
\hline Control & 0 & $24.7 \mathrm{aAB}$ & $23.1 \mathrm{abB}$ & $27.6 \mathrm{aA}$ & $22.1 \mathrm{bcdB}$ \\
\hline \multirow[t]{3}{*}{$\mathrm{GA}_{3}$} & 50 & $24.7 \mathrm{aB}$ & $19.5 \mathrm{cdeC}$ & $24.7 \mathrm{abB}$ & $28.6 \mathrm{aA}$ \\
\hline & 100 & $24.7 \mathrm{aA}$ & $21.8 \mathrm{abcdA}$ & $21.8 \mathrm{bcA}$ & $23.7 \mathrm{bA}$ \\
\hline & 150 & $24.7 \mathrm{aA}$ & $17.1 \mathrm{eC}$ & $20.3 \mathrm{cdBC}$ & $22.6 \mathrm{bcA}$ \\
\hline \multirow[t]{3}{*}{ BA } & 20 & $24.7 \mathrm{aA}$ & $22.3 \mathrm{abcAB}$ & $20.2 \mathrm{cdB}$ & $19.4 \mathrm{cdeB}$ \\
\hline & 40 & $24.7 \mathrm{aA}$ & $18.5 \mathrm{deB}$ & $19.8 \mathrm{cdB}$ & $17.6 \mathrm{eB}$ \\
\hline & 60 & $24.7 \mathrm{aA}$ & $23.5 \mathrm{aAB}$ & $21.0 \mathrm{bcdABC}$ & $19.0 \mathrm{cdeC}$ \\
\hline \multirow[t]{3}{*}{ NAA } & 50 & $24.7 \mathrm{aA}$ & 19.6 bcdeB & $20.7 \mathrm{cdB}$ & $23.3 \mathrm{bAB}$ \\
\hline & 100 & $24.7 \mathrm{aA}$ & 22.7 abcAB & $22.1 \mathrm{bcABC}$ & $18.4 \mathrm{deC}$ \\
\hline & 150 & $24.7 \mathrm{aA}$ & 20.1 abcdeAB & $19.8 \mathrm{cdBC}$ & $18.8 \mathrm{cdeBC}$ \\
\hline
\end{tabular}

\section{Table III.}

The interaction effect of growth regulators and storage period on vitamin C concentration $\left(\mathrm{mg} \cdot 100 \mathrm{~g}^{-1}\right.$ fresh weight) of bisir 'Barhee' dates during cold storage at $1{ }^{\circ} \mathrm{C}$ (Kingdom of Saudi Arabia, 2010 season).

\begin{tabular}{|c|c|c|c|c|c|}
\hline \multirow[t]{2}{*}{ Growth regulator } & \multirow[t]{2}{*}{$\begin{array}{c}\text { Dose } \\
\left(\mathrm{mg} \cdot \mathrm{L}^{-1}\right)\end{array}$} & \multicolumn{4}{|c|}{$\begin{array}{l}\text { Storage period } \\
\text { (days) }\end{array}$} \\
\hline & & 0 & 20 & 40 & 60 \\
\hline Control & 0 & $2.22 \mathrm{aC}$ & $3.33 \mathrm{abAB}$ & $3.55 \mathrm{abA}$ & $2.44 \mathrm{bcBC}$ \\
\hline \multirow[t]{3}{*}{$\mathrm{GA}_{3}$} & 50 & $2.22 \mathrm{aA}$ & $2.44 \mathrm{bcA}$ & $2.44 \mathrm{cA}$ & $2.22 \mathrm{cA}$ \\
\hline & 100 & $2.22 \mathrm{aB}$ & $3.33 \mathrm{abA}$ & $2.88 \mathrm{bcAB}$ & $2.66 \mathrm{bcAB}$ \\
\hline & 150 & $2.22 \mathrm{aB}$ & $2.88 \mathrm{abcAB}$ & $2.88 \mathrm{bcAB}$ & $3.77 \mathrm{aA}$ \\
\hline \multirow[t]{3}{*}{ BA } & 20 & $2.22 \mathrm{aC}$ & $3.10 \mathrm{abcABC}$ & $3.77 \mathrm{abA}$ & $3.33 \mathrm{abAB}$ \\
\hline & 40 & $2.22 \mathrm{aA}$ & $2.44 \mathrm{bcA}$ & $3.11 \mathrm{abcA}$ & $2.88 \mathrm{abcA}$ \\
\hline & 60 & $2.22 \mathrm{aC}$ & $3.33 \mathrm{abAB}$ & $3.66 \mathrm{abA}$ & $2.88 \mathrm{abcABC}$ \\
\hline \multirow[t]{3}{*}{ NAA } & 50 & $2.22 \mathrm{aB}$ & $2.66 \mathrm{bcAB}$ & $3.55 \mathrm{abA}$ & $2.22 \mathrm{cB}$ \\
\hline & 100 & $2.22 \mathrm{aB}$ & $2.88 \mathrm{abcB}$ & $3.99 \mathrm{aA}$ & $2.33 \mathrm{cB}$ \\
\hline & 150 & $2.22 \mathrm{aB}$ & $3.77 \mathrm{aA}$ & $3.99 \mathrm{aA}$ & $2.44 \mathrm{bcB}$ \\
\hline
\end{tabular}


Table IV.

The interaction effect of growth regulators and storage period on weight loss percentage of bisir 'Barhee' dates during cold storage at $1{ }^{\circ} \mathrm{C}$ (Kingdom of Saudi Arabia, 2010 season).

\begin{tabular}{|c|c|c|c|c|c|}
\hline \multirow[t]{2}{*}{ Growth regulator } & \multirow[t]{2}{*}{$\begin{array}{c}\text { Dose } \\
\left(\mathrm{mg} \cdot \mathrm{L}^{-1}\right)\end{array}$} & \multicolumn{4}{|c|}{$\begin{array}{l}\text { Storage period } \\
\text { (days) }\end{array}$} \\
\hline & & 0 & 20 & 40 & 60 \\
\hline Control & 0 & $0.00 \mathrm{aD}$ & $1.82 \mathrm{abcdC}$ & 3.26 cdefB & $5.57 \mathrm{bcA}$ \\
\hline \multirow[t]{3}{*}{$\mathrm{GA}_{3}$} & 50 & $0.00 \mathrm{aD}$ & $1.28 \mathrm{dC}$ & $4.17 \mathrm{aB}$ & $6.84 \mathrm{aA}$ \\
\hline & 100 & $0.00 \mathrm{aD}$ & $1.54 \mathrm{bcdC}$ & $3.79 \mathrm{abcB}$ & $5.98 \mathrm{bA}$ \\
\hline & 150 & $0.00 \mathrm{aD}$ & $1.46 \mathrm{bcdC}$ & $3.38 \mathrm{bcdeB}$ & $5.76 \mathrm{bcA}$ \\
\hline \multirow[t]{3}{*}{$\mathrm{BA}$} & 20 & $0.00 \mathrm{aC}$ & $1.58 \mathrm{bcdB}$ & $4.04 \mathrm{abA}$ & $4.32 \mathrm{dA}$ \\
\hline & 40 & $0.00 \mathrm{aD}$ & $1.62 \mathrm{abcdC}$ & 3.10 defB & $5.65 \mathrm{bcA}$ \\
\hline & 60 & $0.00 \mathrm{aD}$ & $1.44 \mathrm{cdC}$ & 2.74 efB & $4.54 \mathrm{dA}$ \\
\hline \multirow[t]{3}{*}{ NAA } & 50 & $0.00 \mathrm{aD}$ & $2.27 \mathrm{aC}$ & $3.63 \mathrm{abcdB}$ & $5.69 \mathrm{bcA}$ \\
\hline & 100 & $0.00 \mathrm{aD}$ & $2.11 \mathrm{abC}$ & 3.11d efB & $5.21 \mathrm{cA}$ \\
\hline & 150 & $0.00 \mathrm{aD}$ & $2.02 \mathrm{abcC}$ & $2.92 \mathrm{efB}$ & $5.26 \mathrm{cA}$ \\
\hline
\end{tabular}

However, at $150 \mathrm{mg} \mathrm{GA} \cdot \mathrm{L}^{-1}$, it was higher after 60 days of storage than in control fruit. During storage, the concentration of vitamin $\mathrm{C}$ in most treatments including the control tended to increase from day 0 to day 40 and then decreased at day 60 to a level close to the initial level (table III).

The total weight loss percentage significantly increased during storage (table IV). There were no significant differences among the treatments in weight loss percentage after both (20 and 40) days of storage, except for the $\mathrm{GA}_{3}$-treated fruit at $50 \mathrm{mg} \cdot \mathrm{L}^{-1}$, that showed higher weight loss than control fruit. However, after 60 days of storage, the BA-treated fruit at both (20 and 60) $\mathrm{mg} \cdot \mathrm{L}^{-1}$ showed a significantly lower loss in weight than control fruit (table IV).

Fruit ripening as measured by the rutab percentage generally increased during storage in all treatments (table V). After both (20 and 40) days of storage, there were no significant differences in the rutab percentage among fruit of the all treatments. However, after 40 days of storage, both the $\mathrm{GA}_{3}$ - treated fruit at $150 \mathrm{mg} \cdot \mathrm{L}^{-1}$ and the $\mathrm{BA}$ treated fruit at $40 \mathrm{mg} \cdot \mathrm{L}^{-1}$ showed a significantly lower rutab percentage than control fruit (table V). After 60 days of storage, the $\mathrm{GA}_{3}$-treated fruit at $50 \mathrm{mg} \cdot \mathrm{L}^{-1}$ developed a lower rutab percentage than control fruit.

There were no significant interaction effects between growth regulators and storage period for the concentration of titratable acidity, total phenols and soluble tannins.

\section{Discussion}

Our results showed that, to some extent, postharvest dipping in $\mathrm{GA}_{3}, \mathrm{BA}$ and NAA inhibited the ripening and slightly improved quality of cold-stored bisir 'Barhee' dates. This was reflected by the slight but significantly lower TSS concentration, especially in the BA- and NAA-treated fruit, as well as at the highest level of $\mathrm{GA}_{3}$ application (table I). The treated fruit retained a mostly higher concentration of vitamin $\mathrm{C}$ than control fruit. Also, the rutab percentage among treated fruit was significantly 
Table V.

The interaction effect of growth regulators and storage period on the percentage of fruit at the rutab stage of bisir 'Barhee' dates during cold storage at $1{ }^{\circ} \mathrm{C}$ (Kingdom of Saudi Arabia, 2010 season).

\begin{tabular}{|c|c|c|c|c|c|}
\hline \multirow[t]{2}{*}{ Growth regulator } & \multirow[t]{2}{*}{$\begin{array}{c}\text { Dose } \\
\left(\mathrm{mg} \cdot \mathrm{L}^{-1}\right)\end{array}$} & \multicolumn{4}{|c|}{$\begin{array}{l}\text { Storage period } \\
\text { (days) }\end{array}$} \\
\hline & & 0 & 20 & 40 & 60 \\
\hline Control & 0 & $0.0 \mathrm{aD}$ & $19.7 \mathrm{abC}$ & $72.3 \mathrm{aB}$ & $89.7 \mathrm{abA}$ \\
\hline \multirow{3}{*}{$\mathrm{GA}_{3}$} & 50 & $0.0 \mathrm{aD}$ & $12.3 \mathrm{bc}$ & $53.0 \mathrm{abB}$ & $78.9 \mathrm{cA}$ \\
\hline & 100 & $0.0 \mathrm{aD}$ & $25.3 \mathrm{aC}$ & 56.0 defB & 85.7 abcA \\
\hline & 150 & $0.0 \mathrm{aD}$ & $17.7 a b C$ & $51.3 \mathrm{fB}$ & $82.0 \mathrm{bcA}$ \\
\hline \multirow[t]{3}{*}{ BA } & 20 & $0.0 \mathrm{aD}$ & $21.7 \mathrm{aC}$ & $66.3 \mathrm{abcB}$ & $89.7 \mathrm{abA}$ \\
\hline & 40 & $0.0 \mathrm{aD}$ & $12.7 \mathrm{bC}$ & 54.7 efB & $84.0 \mathrm{abcA}$ \\
\hline & 60 & $0.0 \mathrm{aD}$ & $22.7 \mathrm{aC}$ & $72.0 \mathrm{abB}$ & $89.7 \mathrm{abA}$ \\
\hline \multirow[t]{3}{*}{ NAA } & 50 & $0.0 \mathrm{aD}$ & $25.7 \mathrm{aC}$ & $62.0 \mathrm{cdeB}$ & $91.0 \mathrm{aA}$ \\
\hline & 100 & $0.0 \mathrm{aD}$ & $19.0 \mathrm{abC}$ & $64.0 \mathrm{bcdB}$ & $90.0 \mathrm{abA}$ \\
\hline & 150 & $0.0 \mathrm{aD}$ & $22.3 \mathrm{aC}$ & 57.0 defB & $87.7 \mathrm{abA}$ \\
\hline
\end{tabular}

decreased by $\mathrm{GA}_{3}$ application at all rates, $\mathrm{BA}$ at $40 \mathrm{mg} \cdot \mathrm{L}^{-1}$, and NAA at $150 \mathrm{mg} \cdot \mathrm{L}^{-1} \mathrm{com}-$ pared with control and other treatments (table I). The concentration of both titratable acidity and total phenols was not significantly affected by any of the applied treatments (table I).

During the 60 days of storage, the TSS, acidity and vitamin $\mathrm{C}$ concentration, and fruit weight loss and rutab percentage increased, while the concentration of total phenols and soluble tannins decreased (table I). A slight change in TSS and total sugar concentration in 'Barhee' dates as the fruit passed from the bisir to the rutab stage during cold storage has previously been reported by El-Rayes [23]. He also reported that the bisir 'Barhee' dates stored in regular cold storage $\left(0^{\circ} \mathrm{C}\right)$ were totally discarded after 2 months. The decrease in total phenols and soluble tannins during storage as ripening advanced confirm the results of Sawaya [22], Taira [21] and El-Rayes [23]. In our experiment, there were no consistent effects of the applied growth regulators on the measured quality characteristics of fruit for all storage periods (tables II-V), and no superior treatments that effectively inhibited fruit ripening and prolonged storability could be distinguished. Thus, the effective- ness of growth regulators in delaying date ripening, applied as postharvest treatments, seems relatively low in contrast to the preharvest application. Such lack of effectiveness might be due to the difference in the physiological age of the fruit at the time of application (i.e., kimri vs. bisir stage). A physiologically active stage known as the 'depressed period' during the early second sub-stage of the kimri stage was suggested as the most responsive stage to growth regulator treatments [16]. It was reported that the application of $\mathrm{GA}_{3}$ on several date cultivars at the kimri stage delayed fruit ripening and induced a high variation in ripening within the one bunch [14, 15]. Also, the application of NAA at ( 40 and 60$) \mathrm{mg} \cdot \mathrm{L}^{-1}$ on 'Zahdi' dates at the late kimri stage increased fruit size and delayed ripening by one month [16]. Al-Juburi et al. reported that NAA or a mixture of growth regulators (NAA, $\mathrm{GA}_{3}$ and ethephone) application on 'Khenazi' dates, 20 days following pollination, delayed fruit ripening [18]. Also, the application of benzyladenine (BA) and other cytokinines effectively delayed ripening of apples and other fruits [19]. Accordingly, the application of growth regulators at the late kimri stage would possibly inhibit ripening during the subsequent cold storage 
of the bisir 'Barhee' dates. Actually, storage of bisir 'Barhee' dates in modified atmosphere conditions with $20 \% \mathrm{CO}_{2}$ at $0{ }^{\circ} \mathrm{C}$ has been reported to inhibit ripening and maintain quality for up to 170 days [23]. However, such a technique needs more research to confirm its effectiveness for storing bisir 'Barhee' dates with minimal quality losses.

\section{Conclusion}

Dipping the 'Barhee' dates harvested at the bisir stage in $\mathrm{GA}_{3}, \mathrm{BA}$ and NAA solutions at different concentrations showed slight effects on fruit quality characteristics and ripening during subsequent cold storage at $1{ }^{\circ} \mathrm{C}$. A preharvest spray of such growth regulators at an earlier developmental stage (e.g., the late kimri stage) and/or storage in modified atmosphere conditions are suggested for future research.

\section{Acknowledgments}

This work was financially supported by the Deanship of Scientific Research of King Abdul-Aziz University, Saudi Arabia (Project No. 7-004/430). The authors would like to thank Mohamed Ebraheem MSc., Nageeb El-Masoudi Eng. and El-Saied Sabry at the Faculty of Meteorology, Environment and Arid Land Agriculture, King Abdul-Aziz University, Saudi Arabia, for their indispensable technical support.

\section{References}

[1] Vayalil P.K., Antioxidant and antimutagenic properties of aqueous extract of date fruit (Phoenix dactylifera L. Arecaceae), J. Agric. Food Chem. 50 (2002) 610-617.

[2] Mansouri A., Embarek G., Kokkalou E., Kefalas P., Phenolic profile and antioxidant activity of the Algerian ripe date palm fruit (Phoenix dactylifera), Food Chem. 89 (2005) 411-420.

[3] Botes A., Zaid A., The economic importance of date production and international trade, in: Zaid A., Arias E.J. (Eds.), Date palm cultivation, FAO Plant Production and Protection, Paper No. 156, 1999, pp. 45-57.

[4] Awad M.A., Increasing the rate of ripening of date palm fruit (Phoenix dactylifera L.) cv. 'Helali' by preharvest and postharvest treatments, Postharvest Biol. Technol. 43 (2007) 121-127.
[5] Glasner B., Botes A., Zaid A., Emmens J., Date harvesting, packing house management, and marketing aspects, in: Zaid A., Arias E.J. (Eds.), Date palm cultivation, FAO Plant Production and Protection, Paper No. 156, 1999, pp. 177-198.

[6] Awad M.A., Calcium chloride does not influence ripening, quality or calcium content of bisir 'Barhee' dates palm (Phoenix dactylifera L.) during storage at ambient and refrigeration conditions, in: Al-Ghamdi A.S. (Ed.), Proc. 4th Int. Symp. on the Date Palm, King Fasal Univ., Al-Hassa, Saudi Arab., 2007, in press.

[7] Dennis F.G., Apple. In: Monselise S.P. (Ed.), Handbook of fruit set and development, CRC Press, Boca Raton, Florida, USA, 1986.

[8] Yang S.F., Regulation of ethylene biosynthesis, HortScience 15 (1980) 238-243.

[9] Klee H.J., Clark D.G., Manipulation of ethylene synthesis and perception in plants: The ins and the outs, HortScience 37 (2002) 6-8.

[10] Serrano M., Pretel M.T., Botella M.A., Amoros A., Physicochemical changes during date ripening related to ethylene production, Food Sci. Technol. Int. 7 (2001) 31-36.

[11] Hussein M.A., Mahmoud H.M., Ahmed Amin K.I., Mustafa A., Physiological studies for prolonging khalal stage of Zaghloul dates during storage. I. Effect of preharvest application of calcium chloride, in: Al-Ghamdi A.S. (Ed.), Proc. 3rd Int. Symp. on the Date Palm, King Fasal Univ., Al-Hassa, Saudi Arab., 1993, pp. 445-458.

[12] Hussein M.A., Mahmoud H.M., Ahmed Amin K.I., Mustafa A., Physiological studies for prolonging khalal stage of Zaghloul dates during storage. II. Effect of postharvest applications of calcium chloride, in: Al-Ghamdi A.S. (Ed.), Proc. 3rd Int. Symp. on the Date Palm, King Fasal Univ., Al-Hassa, Saudi Arab., 1993, pp. 459-473.

[13] Wills R., McGlasson B., Graham D., Joyce D., Postharvest: An introduction to the physiology and handling of fruit, vegetables and ornamentals, UNSW press, Sydney, Australia, 1998.

[14] Abou-Aziz A.B., Maximos S.S., Desouky I.A., Samra N.R.E., Effect of $\mathrm{GA}_{3}$ and hand pollination on the yield and quality of sewy dates, in: Makki Y.M. (Ed.), Proc. 2nd Int. Symp. on the Date Palm, King Fasal Univ., Al-Hassa, Saudi Arabia, 1982, pp. 258-268.

[15] Hussein M.A., Mahmoud M.H., Amen K.I.A., Mustafa A., Changes in the physical and chemical characteristics of Zaghloul dates during development and maturity as affected 
by $\mathrm{GA}_{3}$ and $\mathrm{CCC}$ under Assuit Governorate conditions, in: Al-Ghamdi A.S. (Ed.), Proc. 3rd Int. Symp. on the Date Palm, King Fasal Univ., Al-Hassa, Saudi Arab., 1993, pp. 389-402.

[16] Mohammed S., Shabana H.R., Effects of naphthaleneacetic acid on fruit size, quality, and ripening of Zahdi date palm, HortScience 15 (1980) 724-725.

[17] Moustafa A.A., Seif S.A., Abou-El-Azayem A., Date fruit response to $\mathrm{N}$ naphthalene acetic acid, in: Al-Ghamdi A.S. (Ed.), Proc. 3rd Int. Symp. on the Date Palm, King Fasal Univ., AlHassa, Saudi Arab., 1993, pp. 369-377.

[18] Al-Juburi H.J., Al-Masry H.H., Al-Banna M., Al-Muhanna S.A., Effect of some growth regulators on some fruit characteristics and productivity of date palm trees (Phoenix dactylifera L.). II. Khaniezy cultivar, in: Al-Badawy A.A. (Ed.), Proc. 2nd Int. Conf. on Date Palms, U.A.E. Univ., Al-Ain, U.A.E., 2001, pp. 21-35.

[19] Greene D.W., Krupa J., Vezina M., Effect of MaxCel on fruit set, fruit size, and fruit characteristics of Summerland McIntosh apples, Fruit Notes 72 (Summer) (2006).
[20] Velioglu Y.S., Mazza G., Gao L., Oomah B.D., Antioxidant activity and total phenolics in selected fruits, vegetables, and grain products, J. Agric. Food Chem. 46 (1998) 41134117.

[21] Taira S., Astringency in persimmon, in: Linskens H.P., Jackson J.F. (Eds.), Modern methods of plant analysis, Vol. 18, Fruit analysis, Springer-Verlag, Berlin Heidelberg, Ger., 1996, pp. 97-110.

[22] Sawaya W.N., Khalil J.K., Khatchadourian H.A., Safi W.M., Mashadi A.S., Sugars, tannins and some vitamins contents of twentyfive date cultivars grown in Saudi Arabia at the khalal (mature color) and tamer (ripe) stages, in: Makki Y.M. (Ed.), Proc. 1st Int. Symp. on the Date Palm, King Fasal Univ., AlHassa, Saudi Arab., 1982, pp. 468-478.

[23] El-Rayes D.A., Effect of carbon dioxide-enriched atmosphere during cold storage on limiting antioxidant losses and maintaining quality of 'Barhy' date fruits, J. King Abdulaziz Univ. Meteorol. Environ. Arid Land Agric. Sci. 20 (2009) 3-22.

Calidad de los dátiles 'Barhee' en el estado bisir almacenados en frío tras inmersión post-cosecha en ácido giberélico, ácido naftaleno y benciladenina.

Resumen - Introducción. Existe una demanda creciente, en el mercado internacional, de los dátiles de calidad excelente, como lo son los del cultivar 'Barhee', consumidos en el estado bisir. Material y métodos. Durante su almacenaje en frío, con respecto a algunas de las características de calidad de los frutos, se estudiaron los efectos del tratamiento de dátiles 'Barhee', en el estado bisir mediante inmersión post-cosecha en soluciones de $\mathrm{GA}_{3}$, BA y ANA, de diferentes concentraciones. Resultados et discussion. La concentración de sólidos solubles totales (SST) en los frutos tratados con BA y NAA fue más floja que en los frutos testigo. Asimismo, los frutos tratados con $150 \mathrm{mg} \mathrm{GA} \cdot \mathrm{L}^{-1}$ mostraron una concentración de SST más floja que los frutos testigo. En relación con los otros tratamientos, aquéllos con $150 \mathrm{mg} \mathrm{GA} \cdot \mathrm{L}^{-1}, 60 \mathrm{mg} \mathrm{BA} \cdot \mathrm{L}^{-1}$ y $(100$ y 150$) \mathrm{mg}$ $\mathrm{NAA} \cdot \mathrm{L}^{-1}$ aumentaron la concentración de vitamina $\mathrm{C}$ de los dátiles. La acidez y la concentración de fenoles totales no se vio afectada por ninguno de los tratamientos. La concentración de taninos solubles de los dátiles tratados sólo resultó ser más alta que la de los frutos testigo, en los frutos tratados con $20 \mathrm{mg} \mathrm{BA} \cdot \mathrm{L}^{-1}$. La pérdida de peso de los frutos tratados con $(20 \mathrm{y}$ 60) $\mathrm{mg} \mathrm{BA}^{-1} \mathrm{~L}^{-1}$ fue inferior a la de los frutos de todos los demás tratamientos, mientras que el tratamiento con $50 \mathrm{mg} \mathrm{GA} \cdot \mathrm{L}^{-1}$ aumentó la pérdida de peso de los dátiles, en relación con los frutos testigo. El porcentaje de dátiles en el estado rutab (índice de maduración de los frutos) fue más flojo en los frutos tratados con $\mathrm{GA}_{3}$ que en los frutos testigo. Además, este porcentaje fue más flojo en los frutos tratados con $40 \mathrm{mg} \mathrm{BA} \cdot \mathrm{L}^{-1}$ y $150 \mathrm{mg} \mathrm{NAA} \cdot \mathrm{L}^{-1}$ que en los frutos testigo. La concentración de SST disminuyó, desde el primer hasta el vigésimo día de almacenaje. Sin embargo, no hubo más descensos de esta concentración tras (40 y 60) días de almacenamiento. Se aumentó ligeramente la acidez durante el almacenamiento. La concentración de vitamina C aumentó hasta 40 días de almacenaje, después se produjo una ligera bajada. La concentración total de fenoles disminuyó tras ( 40 y 60) días de almacenaje, en relación con el nivel inicial. La concentración de los taninos solubles aumentó ligeramente hasta el vigésimo día, pero disminuyó fuertemente tras ( 40 y 60) días de almacenaje, en relación con el nivel inicial. La pérdida de peso de los dátiles y el índice de frutos en el estado rutab aumentaron progresivamente durante el almacenaje. Hubo interacciones significativas entre los reguladores de crecimiento y el período de almacenaje en la concentración de SST y de vitamina C, así como en el índice de pérdida de peso y en el de frutos en el estado rutab.

Arabia Saudita / Phoenix dactylifera / frutas / etapas de desarrollo / almacenamiento en frío / calidad / propiedades fisicoquímicas / maduramiento / madurez 